IRA-International Journal of Management \& Social Sciences

ISSN 2455-2267; Vol.11, Issue 01 (April 2018)

Pg. no. 26-34.

Institute of Research Advances

http://research-advances.org/index.php/RAJMSS

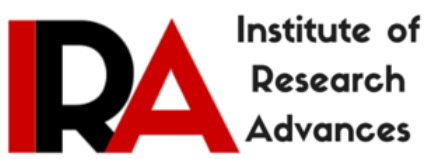

\title{
Economic Growth, Public and Private Consumption in Cameroon: A Multivariate Analysis
}

Honoré Samuel NTAVOUA, $\mathrm{PhD}$

Assistant Lecturer, Faculty of Economics and Management, University of Yaoundé II-SOA, Cameroon.

Type of Review: Peer Reviewed.

DOI: http://dx.doi.org/10.21013/jmss.v11.n1.p3

How to cite this paper:

NTAVOUA, H.S. (2018). Economic Growth, Public and Private Consumption in Cameroon: A Multivariate Analysis. IRA-International Journal of Management \& Social Sciences (ISSN 2455-2267), 11(1), 26-34. doi:http://dx.doi.org/10.21013/jmss.v11.n1.p3

(C) Institute of Research Advances.

\section{(cc) $\mathrm{BY}-\mathrm{NC}$}

This work is licensed under a Creative Commons Attribution-Non Commercial 4.0 International License subject to proper citation to the publication source of the work.

Disclaimer: The scholarly papers as reviewed and published by the Institute of Research Advances (IRA) are the views and opinions of their respective authors and are not the views or opinions of the IRA. The IRA disclaims of any harm or loss caused due to the published content to any party.

Institute of Research Advances is an institutional publisher member of Publishers Inter Linking Association Inc. (PILA-CrossRef), USA. The institute is an institutional signatory to the Budapest Open Access Initiative, Hungary advocating the open access of scientific and scholarly knowledge. The Institute is a registered content provider under Open Access Initiative Protocol for Metadata Harvesting (OAI-PMH).

The journal is indexed \& included in WorldCat Discovery Service (USA), CrossRef Metadata Search (USA), WorldCat (USA), OCLC (USA), Open J-Gate (India), EZB (Germany) Scilit (Switzerland), Airiti (China), Bielefeld Academic Search Engine (BASE) of Bielefeld University, Germany, PKP Index of Simon Fraser University, Canada. 


\begin{abstract}
The nature of the link between economic growth, public and private consumption in theoretical and empirical research is not well known in Cameroon. The objective of this study is to examine the nature of the relationship between economic growth, public and private consumption in Cameroon from 1980 to 2015. In order to achieve our goal, the data from the CENUCED were collected and tested in the autoregressive vector model (VAR). The delay selection statistic for VAR allowed us to have the following causality results: in Cameroon, there is a unidirectional relationship between economic growth towards public consumption and economic growth towards private consumption. Meanwhile, there is no causal link between public and private consumption, from public and private consumption to economic growth. Thus, the recommendation is that the Cameroonian government should create an incentive framework conducive to the improvement of public and private consumption to stimulate investment and economic growth.
\end{abstract}

Keywords: Cameroon, economic growth, public and private consumption, multi-variate analysis, VAR model

\title{
JEL Classification C222 E221 E223
}

\section{Introduction}

Keynesian macroeconomic theory states that consumption and investment play a key role in the process of economic growth by stimulating aggregate demand. Thus, policy makers need to highlight appropriate policies (fiscal and monetary) to boost consumption and investment. Macroeconomic identity in a two or three and four sector economy shows us that the starting point of the demand component is consumption, then the investment and finally the other variables namely; public expenditure and exports. This shows that the contribution of consumption to production is more important than other macroeconomic variables and should receive more attention from policy makers. Consumption and investment are cyclical components of aggregate demand. According to Keynes, consumption is very volatile because the change in income reflects that of consumption. In his famous psychological law, he shows that when income increases, consumption increases less than income. Thus, current income is the determinant of consumption, which may be subject to economic fluctuations.

On the demand side, economic growth is driven by financial variables (interest rates, credit, etc.), investment, exports and consumption. Energy consumption contributes to economic growth in Cameroon according to Molem and al (2016). This same result is observed in the studies developed by the authors such as Ferguson et al (2000), Belke and al (2011), Ahamad and al. (2011) that the opposite case of the contribution of economic growth to energy consumption has been the subject of several studies, but the study of the correlation between economic growth and disaggregated consumption (public and private) remains problematic.

In the context of Cameroon, the pursuit of the objectives of economic growth made it possible to develop economic policies based on economic liberalization in the aftermath of the economic crisis (1986). The fiveyear plans developed in the aftermath of independence have allowed economic growth to improve the welfare of farmers, producers and exporters of agricultural products (cocoa, coffee, cotton, etc.). The decline in production since 1986 has not only deteriorated the purchasing power of the peasants, but led to a decline in consumption and investment. Attempts to increase production by the evidence of structural adjustment programs granted by the IMF and the World Bank in the early 1990s. There was talk of reviving production through devaluation, privatization, fiscal policy austerity etc.

All these measures taken under the structural adjustment programs have had a significant medium and long-term effect on the population. Indeed, in 1995, the Heavily Indebted Poor Countries Initiative (HIPC) process started from the triennial plan (1997-2000), passing through the decision point, admission to the HIPC and reaching the point completion in 2006; has noticeably had an impact not only directly on consumption but indirectly on the basis of the reduction of the imbalance between the supply and demand of employment on the one hand and between the supply and the demand for funds on the other ( the consolidation of the financial system into a market with funds granted under multilateral cooperation). Improved incomes through salary upgrading and non-housing upgrading are not without significant influence on consumption. It is important to note that this situation of improvement of consumption has also been accompanied by the excessive practice of the activity of corruption that the State still manages to curb. from 2008, the fuel pump price subsidy, the raising of the family allowance, the massive recruitment to the public service of 25,000 young people (2011), the exemption of certain tax products and the multiplied actions Ministry of Commerce to control prices, evidence of program budgets; have not only supported household consumption, but also contributed to the rationalization of public 
consumption because one of the missions of donors through the SAPs was to bring Cameroon to live beyond its means.

The main objective of this article is to examine the link between economic growth and public and private consumption in Cameroon. Specifically, this study tries to answer two questions: First, what is the role of public and private consumption in the process of economic growth? Second, how do business cycle conditions (growth variation) influence the disaggregated component of consumption? We will present in the second part the review of the literature, in the third part the methodology adopted, in the fourth part the results, in the fifth part the discussions and in the sixth part the conclusion.

\section{Review of the literature}

\section{II.1. Theoretical review}

It is appropriate in this subsection to theoretically show that consumption has a secondary role in growth on the one hand. On the other hand, it plays a decisive role in economic growth.

Indeed, when it comes to the secondary role, we have the classic analysis of consumption. According to Adam Smith, consumption is not to be taken into account. Only the accumulation of capital and the division of labor are factors of growth at the same time as production. Thus, supply is the only player in growth. Savings are thus preferred to consumption because they are investment factors; it is the demand for production goods that makes it possible to produce more. Ricardo confirms this role of savings. According to Say, commodities trade for commodities to say that economic growth depends on the ability to produce. Similarly in Max Weber's mind the relationship between the ability to save and accumulate capital, and economic growth, to join Ricardo who thinks that saving stimulates economic growth through investment. In Say's model, "products are traded for commodities": economic growth depends on the ability to produce. Secondly, preference for savings and investment among neo-classics and neoliberals, consumption depends on prices so the demand for consumer goods changes according to prices. If these fall, the overall volume of consumption increases. But the fall in prices is conditioned by productivity gains in the company that is to say by investment, hence the recognition of consumption as a secondary factor in relation to investment. Favoring capital in the sharing of added value therefore has a downward effect on prices and increases on investment (thus favorably influences consumption). This corroborates Helmut Schmidt's theorem, which states that "today's profits are the investments of tomorrow and the jobs of the day after tomorrow". Hence savings considered as the main growth factor favors investment. Regarding the assumption that consumption plays a key role in economic growth, it is important to note first that low consumption explains the existence of crises. Indeed, Malthus is opposed to Ricardo that the production requires a prior "will to purchase", that is to say, a request expressed by those who have the means and the will to give the price enough. From where in the time of Malthus, it is necessary to favor the classes which consume. Sismondi and Marx reveal that the lack of consumption explains the crises of overproduction. This insufficiency is a characteristic of capitalism; the evidence of an income-consumption-growth relationship shows that consumption is a component of this demand in the same way as investment. There is a training effect of one on the other (multiplier and accelerator). The accelerator means that a variation in demand leads to a more than proportional variation in investment and therefore in production. Keynes incorporates the importance of consumption into the determinant of the level of production. Thus, $65 \%$ of entrepreneurs set employment according to demand. This relationship between consumption and growth is mechanically illustrated by the national equilibrium equation: GDP $+\mathrm{M}=\mathrm{C}+\mathrm{I}+\mathrm{G}+\mathrm{X}+\Delta \mathrm{S}$ with GDP $=$ Gross Domestic Product, $\mathrm{M}=$ import, $\mathrm{C}=$ consumption, $\mathrm{I}=$ investment, $\mathrm{G}=$ public expenditure, $\mathrm{X}=$ export and $\Delta \mathrm{S}=$ inventory change. When $\mathrm{C}$ increases, GDP increases. Then, from redistribution and welfare state, according to Keynes, the effect of the multiplier is limited by savings. It is therefore necessary to favor consumption, which allows the greatest variation in national income. In this sense, the redistributive economic policy must favor households with the highest propensity to consume, ie the poorest households, the youngest and the oldest, and those who are the most dissaving. Keynes encourages redistribution through taxes, including progressive taxes.

On the other hand, growth also influences consumption. Indeed, we first note Galbraith's reverse-supply theory that supply creates, its own demand for advertising, marketing, consumer credit and low interest rates (leverage and disincentives to savings). Then, referring to the type of growth and consumption, Schumpeter with the intensive growth shows that product, market or energy innovation creates new needs and expands the markets, hence the growth considered as a factor of growth rise in consumption. Unlike extensive growth that increases and decreases consumption, which is considered a source of crisis. Finally Ricardo and Smith in the process of external growth assumes that the expansion of markets, will cause the rise in consumption. But the income 
distributed by the welfare state can be used in other economies, which leads to a decline in domestic consumption. Imports thus mitigate the effect of the Keynesian multiplier.

In the end, the sharing of value added can encourage lower prices or higher wages, which allows an increase in real wages (or purchasing power), which will allow the development of mass consumption. There is also a clear causal relationship between consumption and economic growth. But the theoretical literature is fishing by the fact that it does not explain the disaggregated case of consumption and that is the reason why we want to test the causality between economic growth and public and private consumption.

\section{II.2. Empirical review}

With regard to the link between consumption and economic growth, it is important to note that there is an important literature on this link. However, a lot of literature is concerned about energy consumption (electricity) on economic growth. This is because electricity plays a vital role in the production and consumption of goods and services in an economy. For example, Ferguson et al (2000) find a strong correlation between electricity use and growth and economic development in a study of more than 100 countries. However, this strong correlation does not imply a causal relationship between energy consumption and economic growth.

According to the surveys conducted by Payne (2010), 31.15\% support the hypothesis of neutrality, that is to say, a lack of a causal relationship between electricity consumption and economic growth. $27.87 \%$ support the unidirectional hypothesis, so the causality that goes from economic growth to consumption of electricity; $22.95 \%$ support the hypothesis of the link between energy consumption and economic growth and $18.03 \%$ support the hypothesis of feedback, that is to say a reciprocal relationship between energy consumption and economic growth.

Recent studies by Belke and al. (2011) examine the long-run relationship between consumption and real GDP. It appears that international development dominates the long-term relationship between energy consumption and real GDP. There is indeed a double causality, but the price of energy consumption is elastic. Unlike Gurgul and al. (2011) who study the causal link between GDP and coal consumption in economic policy. He finds the hypothesis of neutrality. In Bangladesh, the recent study by Ahamad and al. (2011), reveals that in the short term there is a one-way relationship that ranges from electricity consumption to GDP per capita. This study indicates that an increase in electricity consumption affects economic activity in Bangladesh in the short term and in the long term there is a two-way causality ranging from electricity consumption to growth and vice versa. In the context of Cameroon, the most recent study is that of Molem and al. (2016) examining the effect of energy use on economic growth. The application of the generalized moments show that there is a positive and significant relationship between energy consumption and economic growth. They conclude that the consumption of energy plays a very important role in the Cameroonian economy.

While there is a link between sectoral consumption and economic growth in Cameroon, the relationship between consumption (public and private) and economic growth is problematic. Starting from this limit, this study aims to establish the link between economic growth and consumption (public and private). An econometric study conducted by the Department of Economic and Financial Studies (DEEF, 1996) in Morocco between consumption and investment shows that the increase in consumption in 1974 was mainly driven by the increase in public investment. The entry into the phase of structural adjustments, since the beginning of the eighties, made it possible to reduce the rate of public investment in favor of a higher rate of private investment. A $1 \%$ drop in public investment would lead to a $0.4 \%$ decline in overall investment. This effect mainly affects private investment. A drop in public investment, which contributes to a decrease in the crowding-out effect, can offset the negative direct effect of this fall on overall investment (by the interest rate and the increased confidence of operators).

Zulkefly and al. (2012) conducted a study on the causality test between investment, consumption and economic growth in malaria. From a structural error correction model, it appears that investment and consumption have a positive and significant influence on economic growth in the short term. In the long run this impact is not significant but rather a significant effect of economic growth on consumption and investment. That is to say that, on the demand side, the tax policy highlighted stimulates investment and consumption, hence their impact on economic activity. Thus a supply policy would be needed to stimulate long-term economic activity.

It follows from the above that there is a large number of studies of the effect of sectoral consumption on economic growth. That of the consumption of electricity or of energies makes the front page of the literature. It 
is for this reason that we join in other ways, relying on the theoretical work of the neoliberal and Keynes who advocate a controversy around the role of aggregate consumption on economic growth and vice versa. It is indeed a question of providing empirical evidence on the correlation that might exist between economic growth and disaggregated consumption (public and private).

\section{Research methodology}

The methodology of this study begins with the analysis of the nature and source of the data. Then, the model specification and finally, after reviewing the unit root test, the application of estimation tectonics will follow.

\section{III.1. Data sources}

The data used are of the secondary type applied to a longitudinal cross-sectional analysis from 1980 to 2015. They come from the database of UNCTAD STAT (2016). STATA.11 software is used for model processing and estimation.

\section{III.2. Model specification}

The econometric approach highlighted is that of multi-varied time series. They make it possible to relate several socio-economic variables. More specifically, the autoregressive vector (VAR) model is applied. The particularity of this is the study of simultaneity or causality between macroeconomic variables. It is characterized by its simplicity and the possibility of estimating small sizes. the variables explained are on both sides considered in other equations as explanatory variables and vice versa, these delayed variables of the period are considered as instrumental variables which make it possible not only to make the technique used robust, but to solve the possible problem of fallacious regression. We were inspired by the work of Ngouhouo and al. (2014), Elżbieta and al. (2016), to write the model opposite, whose variables take the form of logarithm.

$$
\begin{aligned}
& \operatorname{LogCRO}_{t}=F\left(\operatorname{LogCPU}_{t}, \log C P R_{t}, \operatorname{LogINV}_{t}, \operatorname{LogINF}_{t}, \operatorname{TCH}_{t}, \operatorname{LogTIN}_{t}, \operatorname{LogCRO}_{t-i}, \varepsilon_{1 . t}\right) \\
& \operatorname{LogCPU}_{t}=F\left(\operatorname{LogCRO}_{t}, \operatorname{LogCPR}_{t}, \operatorname{LogINV}_{t}, \operatorname{LogINF}_{t}, \operatorname{LogTCH}_{t}, \operatorname{LogTIN}_{t}, \operatorname{LogCPU}_{t-i}, \varepsilon_{2 . t}\right) \\
& \operatorname{LogCPR}_{t}=F\left(\operatorname{LogCPU}_{t},{\log C R O_{t}}_{1} \operatorname{LogINV}_{t}, \operatorname{LogINF}_{t}, \operatorname{TCH}_{t}, \operatorname{LogTIN}_{t}, \operatorname{LogCPR}_{t-i}, \varepsilon_{3 . t}\right.
\end{aligned}
$$

With t: Study period (1980 to 2015); t-i, the value $t$ delayed by i period (number of delays); cjt: the stochastic error term (mean zero and constant variance); Log: the logarithm (on all variables).

CRO: Economic growth measured by real GDP in current dollars

CPU: Public consumption as measured by general government consumption expenditure in current dollars

CPR: Private consumption measured by household expenditure in current dollars

INV: Investment is measured by gross fixed capital formation in current dollars

INF: Inflation measured by the consumer price index

TIN: Interest Rates

TCH: Exchange rate

\section{III.3. Unit root test}

In order to perform the VAR model that must be used to test the causal relationships between the variables, it is necessary that the time series in logarithmic form be stationary at level or first difference. This study avoids the case of fallacious regression. Detection of stationarity is performed by an enhanced Dickey-Fuller (ADF) test. The delay number of the time series in the ADF test is based on the Schwarz criterion. Depending on the logadjusted data development, an equation of the stationarity test includes a coefficient in case of CRO, CPU and CPR or it includes a trend coefficient. This is demonstrated by the following equation:

$$
\Delta X_{t}=\alpha_{0}+\alpha_{1} X_{t}+\alpha_{2} X_{t-1}+\sum_{i=0}^{k} \alpha_{3} \Delta X_{t-i}+u_{t}
$$

The ADF test is used to determine a unit root $\mathrm{Xt}$, at the level of each variable computed by logarithm in time $\mathrm{t}$. The variable $\llbracket \Delta X \rrbracket_{-}(\mathrm{t}-\mathrm{i})$ determines the first difference with the number of delays and ut suggests the autocorrelation of the error. The coefficients $\alpha \mathrm{i}$ are suggested. The null and alternative hypothesis for the existence of a unit root in the variable Xt is as follows: H0: $\alpha 2=0 ; \mathrm{H1}: \alpha 2<0$, Dickey and Fuller (1979)

If the probability value is less than any significance level, reject $\mathrm{H} 0$ and conclude that the series is stationary; otherwise it is said to be tainted with unit root. Comparing the student's calculated statistic value of $t$ with that read at any level of significance also allows us to conclude whether or not the series has a unit root. 


\section{III.4. Estimation technique}

To estimate the VAR model, one must first determine the number of delays of different variables of the model. The criteria used to select delays are: Akaike Information Criteria (CIA), Schwarz Criteria (CS), Hannan-Quinn Criterion (HQ); the final prediction criterion (FPC) and the long-term criterion (LR). Whoever presents the minimum delay is preferred to others. This result will start from the test or diagnosis of the VAR model. In this case, if the minimum delay is $\mathrm{p}$, the number of delays to be used according to the Toda-Yamamoto method will be equal to $(p+1)$, that is to say the minimum criterion increased by one. In the specific case of the VAR model, the number of significant delays reflects the goodness of the model. Following the choice of delay number, the estimation of the VAR model is done using the delay selection statistics for VAR and model of the error correction vector (VECM).

\section{Results}

Table 1 shows the unit root test results of all individual variables. The ADF test has been highlighted.

Table 1: Unit Root Test Results

\begin{tabular}{|c|c|c|c|c|c|c|}
\hline \hline Variables & Test & P-Value & calculated t-student & $\begin{array}{c}\text { read } \\
\text { t-student }\end{array}$ & $\begin{array}{c}\text { Order } \\
\text { integration }\end{array}$ & Décision \\
\hline LogCRO & ADF & 0.0034 & -3.758 & $-3.682^{*}$ & $\mathrm{I}(0)$ & Stationary \\
\hline LogCPU & ADF & 0.7985 & -0.868 & 3.689 & - & Non Stationary \\
\hline LogCPR & ADF & - & 2.102 & $-1.950^{* *}$ & $\mathrm{I}(0)$ & Stationary \\
\hline LogINV & ADF & - & 1.632 & $-1.604^{* * *}$ & $\mathrm{I}(0), \mathrm{I}(1)$ & Stationary \\
\hline LogINF & ADF & - & 4.408 & $-2.644^{*}$ & $\mathrm{I}(0)$ & Stationary \\
\hline LogTIN & ADF & 0.0177 & -3.241 & $-2.972^{* *}$ & $\mathrm{I}(0)$ & Stationnaire \\
\hline LogTCH & ADF & 0.3231 & -1.919 & -3.682 & - & Non stationnaire \\
\hline \hline
\end{tabular}

Source: Author Note: Stationary: $\quad \grave{a} *=1 \% ; * *=5 \% ; * * *=10 \%$.

The table shows that there are two non-stationary and five stationary variables. In fact, the variables CRO, CPR, INF, and TIN are stationary at level I (0) and the variable INV stationary at level and at the first difference, ie I (0) and I (1). The CPU variable is stationary neither level nor at first difference, and Philip's perron test application confirms the result of ADF. The VAR model used to use with delayed CPU evidence solves the estimation problem. Table 2 opposite allows us to have the number of delays prior to the estimate. The VAR model test or diagnostic is highlighted with the application of the delay order selection statistic.

\section{Table 2: Result of delay criterion}

\begin{tabular}{|c|c|c|c|c|c|}
\hline \multirow{2}{*}{ Delay } & LL & LR & FPE & AIC & HQIC \\
\hline 0 & 43.2478 & & 0.005693 & -2.33857 & -2.23302 \\
\hline 1 & 46.817 & 7.1385 & 0.004843 & -2.50432 & -2.38369 \\
\hline 2 & 46.8434 & 0.05272 & 0.005184 & -2.44151 & -2.3058 \\
\hline 3 & 51.8075 & $9.9283^{*}$ & $.004041^{*}$ & $-2.69726^{*}$ & $-2.54647^{*}$ \\
\hline 4 & 52.6503 & 1.6855 & .004117 & -2.68711 & -2.52125 \\
\hline
\end{tabular}

Source: Author 
The table shows that the minimum delay is 3 with LR, FPE, and AIC. Since there is a variable CPU, dependent (model 2) and independent (model 1 and 3), knowing that a large number of delays leads to goodness of model, the method of Toda-Yamamoto allows us to choose $r+1$ delay, the number of delays equal to 4 .

Table 3 shows the estimation of the defined models. The first is that of economic growth, the second that of public consumption and the last represents the model of private consumption. The delay selection statistic for VAR used shows that the independent variables account for growth, public and private consumption at $94.55 \%$, $99.21 \%$ and $99.58 \%$, respectively. This goodness is supported by the null probability and largely superior to chi2.

Table 3: Model Result

\begin{tabular}{|c|c|c|c|c|c|}
\hline \multicolumn{6}{|c|}{$\begin{array}{l}\text { Estimation of the VAR model } \\
\text { Period: } 1980 \text { to } 2015\end{array}$} \\
\hline \multicolumn{2}{|c|}{ Model 1 : $\operatorname{LogCRO}$} & \multicolumn{2}{|c|}{ Model 2 : LogCPU } & \multicolumn{2}{|c|}{ Model3 : LogCPR } \\
\hline $\begin{array}{l}\text { Independent } \\
\text { variables }\end{array}$ & $\begin{array}{l}\text { Coefficient } \\
\text { (P-value) }\end{array}$ & $\begin{array}{l}\text { Independent } \\
\text { variables }\end{array}$ & $\begin{array}{l}\text { Coefficient } \\
\text { (P-value) }\end{array}$ & $\begin{array}{l}\text { Independent } \\
\text { variables }\end{array}$ & $\begin{array}{l}\text { Coefficient } \\
\text { (P-value) }\end{array}$ \\
\hline $\log C R O(-1)$ & $\begin{array}{l}0.1312308 \\
(0.405)\end{array}$ & $\log C P U(-1)$ & $\begin{array}{ll}0 & 0 \\
(0.001)^{*} & .2510811 \\
\end{array}$ & $\log C P R(-1)$ & $\begin{array}{l}0.4157314 \\
(0.000)^{*}\end{array}$ \\
\hline $\log C R O(-2)$ & $\begin{array}{l}-0.301823 \\
(0.008)^{*}\end{array}$ & $\log C P U(-2)$ & $\begin{array}{l}-0.1309028 \\
(0.062)^{* * * *}\end{array}$ & $\log C P R(-2)$ & $\begin{array}{l}-0.1768115 \\
(0.019)^{* *}\end{array}$ \\
\hline $\operatorname{LogCRO}(-3)$ & $\begin{array}{l}0.0859127 \\
(0.388)\end{array}$ & $\log C P U(-3)$ & $\begin{array}{l}0.1212225 \\
(0.058)^{* * * *}\end{array}$ & $\log C P R(-3)$ & $\begin{array}{l}-0.0085098 \\
(0.903)\end{array}$ \\
\hline $\log C R O(-4)$ & $\begin{array}{l}-0.1229384 \\
(0.358)\end{array}$ & $\log C P U(-4)$ & $\begin{array}{l}0.0656193 \\
(0.188)\end{array}$ & $\log C P R(-4)$ & $\begin{array}{l}0.0687939 \\
(0.168)\end{array}$ \\
\hline LogCPU & $\begin{array}{l}0.6744674 \\
(0.621)\end{array}$ & LogCRO & $\begin{array}{l}-0.0747467 \\
(0.077)^{* * * *}\end{array}$ & LogCPU & $\begin{array}{l}0.0629041 \\
(0.607)\end{array}$ \\
\hline LogCPR & $\begin{array}{l}0.0800848 \\
(0.931) \\
\end{array}$ & LogCPR & $\begin{array}{l}0.0863649 \\
(0.664)\end{array}$ & LogCRO & $\begin{array}{l}-0.0584673 \\
(0.035) * *\end{array}$ \\
\hline LogINV & $\begin{array}{l}-0.4286571 \\
(0.614)\end{array}$ & LogINV & $\begin{array}{l}0.5500576 \\
(0.000)^{*}\end{array}$ & LogINV & $\begin{array}{l}0.2890858 \\
(0.000)^{*}\end{array}$ \\
\hline LogINF & $\begin{array}{l}2.211235 \\
(0.064) * * *\end{array}$ & $\operatorname{LogINF}$ & $\begin{array}{r}0.390297 \\
(0.080)^{* * * *}\end{array}$ & LogINF & $\begin{array}{l}0.8121143 \\
(0.000)^{*}\end{array}$ \\
\hline LogTIN & $\begin{array}{l}0.4226385 \\
(0.003)^{*}\end{array}$ & $\log T I N$ & $\begin{array}{l}0.0585453 \\
(0.091)^{* * * *}\end{array}$ & $\log \mathrm{TIN}$ & $\begin{array}{l}-0.0283529 \\
(0.229)\end{array}$ \\
\hline $\operatorname{LogTCH}$ & $\begin{array}{l}-1.228006 \\
(0.038)^{* * *}\end{array}$ & $\operatorname{LogTCH}$ & $\begin{array}{l}-0.4700296 \\
(0.001)^{*}\end{array}$ & $\mathrm{LogTCH}$ & $\begin{array}{l}-0.5000144 \\
(0.000)^{*}\end{array}$ \\
\hline $\mathrm{C}$ & $\begin{array}{l}18.28206 \\
(0.176)\end{array}$ & $\mathrm{C}$ & $\begin{array}{l}3.593992 \\
(0.183)\end{array}$ & $\mathrm{C}$ & $\begin{array}{l}9.608803 \\
(0.000)\end{array}$ \\
\hline $\mathrm{R}^{2}$ & 0.9455 & & 0.9921 & & 0.9958 \\
\hline $\mathrm{p}$-Value & 0.0000 & & 0.0000 & & 7430.829 \\
\hline chi2 & 537.3013 & & 3913.681 & & 0.0000 \\
\hline
\end{tabular}

Source; Author Note: Significant to $1 \%=*, 5 \%=* *, 10 \%=* * *$,

\section{Discussions}

The first model in Table 3 shows that delayed growth of two periods and the exchange rate have a significant and negative influence on economic growth. Thus, an increase in TCH of $1 \%$ leads, all things being equal, to a decrease in economic growth of $1.228 \%$. Inflation and the interest rate have a significant and positive influence on economic growth. Thus, the increase in inflation of $1 \%$ leads to an increase in economic growth of $2.211 \%$, moreover, the increase in the interest rate of $1 \%$ leads to an increase in economic growth of $0.423 \%$. Public and private consumption does not cause economic growth.

The second model shows that the delayed public consumption of the first three periods has a significant influence on the public consumption of period t. Investment, interest rate and inflation significantly and 
positively influence public consumption. Thus, a respective increase of these variables by $1 \%$ results in all things being equal, an increase in the respective CPU of $0.550 \%, 0.058 \%, 0.390 \%$. The exchange rate, as in the case of the first model, has a significant and negative influence on public consumption. Economic growth causes public consumption and private consumption does not cause it.

The third model shows that delayed private consumption of the first two has a significant influence on private consumption in period $t$. Investment and inflation have a significant and positive influence on private consumption. Thus, a respective increase of these variables of $1 \%$ results in all other things being equal, an increase of the respective CPR of $0.289 \%, 0.812 \%$. Increasing economic growth by $1 \%$ results in a CPR decrease of $0.058 \%$. Economic growth causes private consumption and public consumption does not cause it. From the synthesis of causal relations, there is a unidirectional relationship of economic growth towards public consumption on the one hand; and on the other hand from economic growth to private consumption. Indeed, the first link is explained by the fact that there is a correlation between the evolution of economic growth and the budget. The budget devoted to the operation is considered as public consumption of the State. The return of positive economic growth since 1995 and the breath of fresh air after completion of the completion point in 2006, also reflect the fact that economic growth is causing public consumption. From the second causality, the facts are those explained previously. But we note in particular that the return of economic growth has favored household income for consumption. The promotion of public-private partnership and attractiveness of investments have fostered economic growth, which has caused private consumption.

There is no causal relationship between public and private consumption towards economic growth, and between public and private consumption reciprocally.

\section{Conclusion}

The main objective of the study was to examine the nature of the relationship between economic growth, public and private consumption in Cameroon. Using a quantitative study, objectives were partially achieved for most variables. Economic growth has a causal link with public and private consumption, Public and private consumption has no effect on economic growth, which is contrary with the case of energy consumption verified by Molem and al. (2016) in the case of Cameroon. Other analyzes could determine the quality of public consumption; the correlation between public and private consumption; incentives for consumption (public and private) favorable for investment and economic growth.

\section{References}

[1] ADAMS, S. (2009).Foreign direct investment, domestic investment, and economic growth in Sub-Saharan Africa. Journal of Policy Modeling, 31, 939-949

[2] AHAMAD, M. G., \& ISLAM, N. (2011). Electricity consumption and economic growth nexus in Bangladesh: Revisited evidences. Energy Policy, 39, 6145-6150

[3] ANSGAR, B. DREGER, C. AND FRAUKE, D. (2010).Energy consumption and economic growth: New insights into the co-integration relationship. Ruhr Economic Papers, 190, 1-24.

[4] BELKE, A. DOBNIK, F., \& DREGER, C. (2011). Energy consumption and economic growth: new insights into the co-integration relationship. Energy Economics, 33, 782-789.

[5] BLOMSTROM, M., LIPSEY, R., AND ZEJAN, M. (1996). Is fixed investment the key to economic growth. The Quarterly Journal of Economics, 111, 269-276.

[6] CHANDRAN, V. G. R., SHARMA, S., \& MADHAVAN, K. (2010). Electricity consumption-growth nexus: The case of Malaysia".Energy Policy, 38, 606-612

[7] DICKEY, D., AND FULLER, W. (1979). Distribution of the estimator for autoregressive time series with a unit root. Journal of the American Statistical Association, 74(366a): 427-431.

[8] ERDAL, G., ERDAL, H. AND ESENGUN, K. (2008). The causality between energy consumption and economic growth in Turkey.Energy Policy, 36(10): 3838-3842.

[9] [9]FERGUSON, R., WILKINSON, W., AND HILL, R. (2000). Electricity use and economic development. Energy Policy, 28, 923-934.

[10] GURGUL, H., \& LACH, L. (2011). The role of coal consumption in the economic growth of the Polish economy in transition. Energy Policy, 39, 2088-2099.

[11] INS. (2010). Annuairestatistique du Cameroun. 1-17.

[12] JOHANSEN, S. (1991). Estimation and hypothesis testing of co-integration vectors in Gaussian vector autoregressive models. Econometric, 59(6): 1551-1580.

[13] MANKIW, N. G., ROMER, D AND WEIL, D. N. (1992). A contribution to the empirics of economic growth. The Quarterly Journal of Economics, 107, 407-437.

[14] MOLEM, C. S., AND NDIFOR. R. (2016). The effect of energy consumption on economic growth in Cameroon. Asian Economic and Financial Review, 6(9): 510-521 
[15] NGOUHOUO, I., \& MOUCHILI, E. (2014). Saving, Investment and Economic Growth in Cameroun: A Multivariate Approach International. Journal of Economics and Finance; 6(9) 244-256.

[16] ONGONO, P. (2009). Energy consumption and economic performance in Cameroon.MPRA Paper No. 23525, posted 27, 1-31

[17] PAYNE, J. E. (2010). A survey of the electricity consumption-growth literature. Applied Energy, 87, 723-731.

[18] PAYNE, J. E. (2008). Survey of the international evidence on the causal relationship between energy consumption and growth. Journal of Economic Studies, 37, 53-95.

[19] STERN, D.I. (1993). Energy use and economic growth in the USA: A multivariate approach. Energy Economics, 15(2): $137-150$.

[20] TANG, C. F. (2008). A re-examination of the relationship between electricity consumption and economic growth in Malaysia.Energy Policy, 36, 3077-3085.

[21] TODA, H.Y., AND YAMAMOTO, T. (1995). Statistical inference in vector auto regressions with possibly integrated processes. Journal of Econometrics, 66(1): 225-250.

[22] YOO, S. H. (2006). The causal relationship between electricity consumption and economic growth in the ASEAN countries. Energy Policy, 34, 3573-3582.

[23] ZULKEFLY, K., BAKRI, A. K.; AND MOHD, A. S. (2012). Fixed investment, household consumption, and economic growth: a structural vector error correction model (SVECM) study of Malaysia. 13(1), 63 -76. 